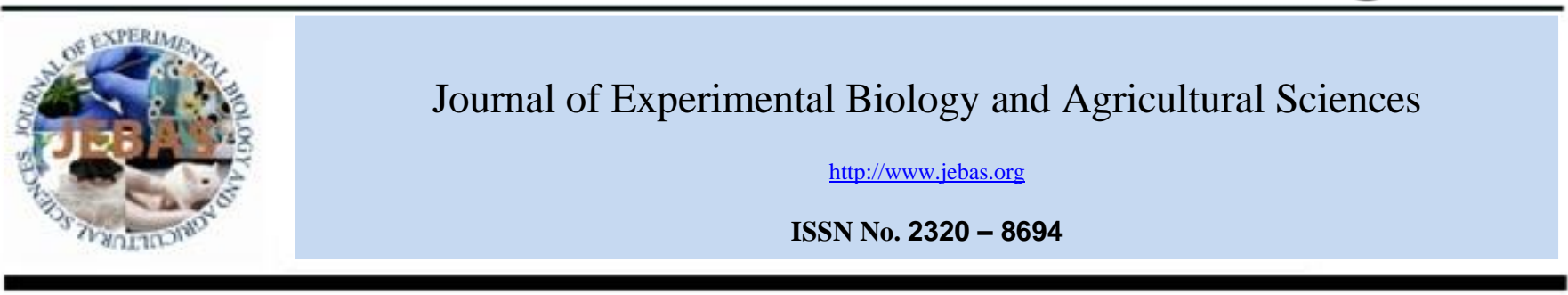

\title{
EFFECT OF NON-CATALYTIC INFRARED RAY ON THE GRAIN MOTH Sitotroga cerealella (LEPIDOPTERA: GELECHIIDAE)
}

\author{
Hussam Aldin Abdullah ${ }^{1,}$, Taha A. Elwi ${ }^{2}$, Azhar M.Ali ${ }^{1}$, Alaa H. Taher ${ }^{1}$ and Marawh Thamer $^{3}$ \\ ${ }^{1}$ Department of Plant Protection, College of Agriculture, Baghdad University, Baghdad, Iraq \\ ${ }^{2}$ Department of Communication Engineering, Al-Mammon University Collage, Baghdad, Iraq \\ ${ }^{3}$ Ministry of Science and Technology, Iraq
}

Received - November 02, 2016; Revision - January 01, 2017; Accepted - April 21, 2017

Available Online - May 12, 2017

DOI: http://dx.doi.org/10.18006/2017.5(2).264.270

KEYWORDS
Non-catalytic infrared waves
Grain moth
Sitotroga cerealella
Wheat
Stored grains

\begin{abstract}
This study was conducted under laboratory conditions to find out the effect of the non-catalytic infrared on the mortality rates and development of various stages of the grain moth Sitotroga cerealella. Result of the study revealed that treated eggs, first and fourth instars, pupae and adults mortality increased by increasing non-catalytic infrared waves exposure time from 40 and 60 seconds at 40 and $50^{\circ} \mathrm{C}$. Highest egg mortality (56.7\%) and hatching period (6.1 days) was reported on the exposure of 60 seconds at $50^{\circ}$ $\mathrm{C}$ while the lowest values $3.3 \%$ and 4.5 days respectively was reported for the control treatments. Similar conditions were reported for the first and fourth instars, pupae and adults mortality. Infrared waves exposure for 60 seconds at $50^{\circ} \mathrm{C}$ significantly influenced the development of S. cerealella and showed $53.31 \%$ first stage larval mortality, $50 \%$ fourth stage larval mortality, $46.7 \%$ pupal mortality and $66.7 \%$ adult mortality. Furthermore, it was reported that infrared wave did not have any negative effect on the seed germination and 60 second exposure at $50{ }^{\circ} \mathrm{C}$ showed 96 percent seeds germination.
\end{abstract}

* Corresponding author

E-mail: hussam_patho@yahoo.com (Hussam Aldin Abdullah)

Peer review under responsibility of Journal of Experimental Biology and Agricultural Sciences.

Production and Hosting by Horizon Publisher India [HPI] (http://www.horizonpublisherindia.in/).

All rights reserved.
All the article published by Journal of Experimental Biology and Agricultural Sciences is licensed under a Creative Commons Attribution-NonCommercial 4.0 International License Based on a work at www.jebas.org.

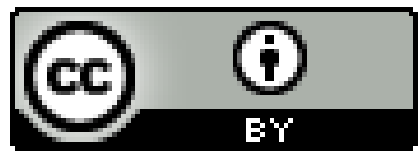




\section{Introduction}

The economic loss due to stored grain pest is a serious problem worldwide. About 200 insect species were reported from stored grains and among these, angoumois grain moth, Sitotroga cerealella (Olivier) (Lepidoptera Gelechiidae), is considered as common, top of the list and most destructive pest of stored grain especially for store grains. Mostly, infestations of $S$. cerealella reported at postharvest stage, but sometime this insect also attacked preharvest or at the fruiting stage. The damage caused by $S$. cerealella is crucial under both temperate and tropical conditions (Germanov, 1982). The larvae of S. cerealella attack a variety of kernels, such as corn, barley, sorghum, wheat, soybean, rice, paddy and other stored cereal grain. Further, S. cerelella can also attack on the stored spices such as piper, Coriander, ginger, turmeric and many other non crop wild plants (Dakshinamurth \& Regupathy, 1988; Ukeh et al., 2008; Pan et al., 2008; Ashamo, 2010; Trematerra et al., 2011; Trematerra, 2015). In case of store wheat grain, Khan et al. (2010) reported that about 12 wheat genotypes were damaged by S. cerelella and it causes annually 19.2-58.2\% dame and $12.19-40.93 \%$ losses. Newly hatched S. cerealella caterpillar bores into the grain and usually complete larval and pupal stage here without showing any visible symptom (Weston \& Rattlingourd, 2000). S. cerealella larvae mostly feed on the seed endosperm. Under favourable conditions $\left(30^{\circ} \mathrm{C}\right.$ and $80 \%$ relative humidity) $S$. cerealella complete its larval development in 19 days only (Hill, 1990). Further it was reported that temperature and humidity are the two factors which influence the rate of larval development and Grewal \& Atwal, (1967) suggested that 25 $30^{\circ} \mathrm{C}$ temperature and $80 \% \mathrm{RH}$ are most favourable for development, survival and reproduction of $S$. cerealella. Later on Hansen et al. (2004) suggested that high relative humidity and temperatures higher than $30^{\circ} \mathrm{C}$ negatively influenced the development of this insect.

Although there are many control strategies such as use of edible oils, synthetic chemicals, plant derivatives, bacterial protoxins, biopesticides, biocontrol enhancers and semiochemicals are available for the management of $S$. cerealella but the most commonly used method is fumigation with the help of hazards chemicals. These chemicals are not only hazards for human being but also caused serious environmental pollution also. By keeping these facts in consideration, there is a dire need to explore the alternate and environment friendly method of pest management which should be cheap and readily available (Rajendran \& Chayakumari, 2003; Ashamu \& Khanna, 2006; Butron et al., 2008).

Heat can be used for the management of store grain pest by using phenomena thermal lethality. Heat can be generate by many ways, among this use of electromagnetic energies is the most common one. Infrared radiation is harmless electromagnetic radiation with $700 \mathrm{~nm}$ to $1 \mathrm{~mm}$ wavelengths. These waves have higher wavelengths than those of visible light (Penner, 1998). Infrared radiation is strongly emitted from hot objects, and can be easily absorbed by living tissues so it can be used in insect pest management (Tilton \& Schroeder, 1963). Infrared radiation is quickly absorbed by water particles and causing sudden increases in the body temperature (Wehling, 1998). The moisture content of insects is reported up to $60 \%$ while in seed grains water content is limited and it is up to $11-13 \%$. Under this situation, insects will receive a lethal dose of IR energy; as a result, this technology can substitute the use of traditional chemical like the phosphine and it can be used as an alternative in store grain insect pest management (Khamis et al., 2010). Khamis et al. (2011) reported high level Rhyzoperth dominica mortality when they used flameless catalytic infrared omitter. Athanassiou et al. (2016) artificially infested Corinthian currants by Ephestis elutella larvae and adults of the Oryzaephilus surinamensis and Tribolium confusum and treated these with IR in agitating flow process at different temperature $\left(45,50,55,60,65\right.$ and $\left.70 \mathrm{C}^{\circ}\right)$ and exposure time $(1,2,3,4,5,8,10$ and 20 s). Results of study revealed that all IR treatment provided maximum insect control. Similarly, Duangkhamchan et al. (2017) tested efficacy of infrared heating method $\left(50-60^{\circ} \mathrm{C}\right)$ against rice weevils Sitophilus oryzae eggs and reported $100 \%$ insect mortality at 2 minutes exposures. Present study was conducted to find out the lethal effect of the non-catalytic infrared radiation on grain moth Sitotroga cerealella.

\section{Materials and Methods}

\subsection{Materials}

For this study, insect population of S. cerealella (Lepidoptera: Gelechiidae) was provided by the Ministry of Science and Technology, IPM Centre, Entomology Lab, Baghdad, Iraq. Twenty pairs of collected insects were reared on $250 \mathrm{gm}$ wheat seeds in plastic containers $(14 \times 7.5 \mathrm{~cm})$ incubated at $28 \pm 2^{\circ} \mathrm{C}$ temperature and $20 \%$ relative humidity.

Infrared radiation was generated by IR device with Halogen bulb of tungsten heat radiator in quartz tubes (Commercially known as Halo Theram, made by Osram - America). This device can generate IR energy (up to $1100 \mathrm{~nm}$.). The device was provided with a cooler and thermometer to monitor the temperature as mentioned in Technical Data (2016).

\subsection{Experimental procedures}

\subsubsection{Effect of infrared ray on 24 hours old eggs of S. cerealella}

Three exposure times (15, 30 and 60 seconds) and two temperatures $\left(40 \& 50{ }^{\circ} \mathrm{C}\right.$.) with three replicates were used in this study. Twenty four hours old ten eggs were collected in $9 \mathrm{~cm}$. diameter Petri dishes for each exposure time and temperatures. All treatments, (except the control dishes), were exposed to the IR for selected range of temperatures and time periods. Petri dishes which subjected to the treatments were kept under the I.R. device. All experimental dishes were supplied with $5 \mathrm{gm}$ of nutrient powder to feed hatching larvae. After treatment, all the treated and control Petri dishes were covered with mousseline cloth and incubated in an incubator at $30 \pm 2{ }^{\circ} \mathrm{C}$ temperature and $70 \pm 5 \%$ R.H. Mortality and hatching percentage were recorded at regular interval till the completion of study. 
2.2.2 Effect of the infra-red ray on $1^{\text {st. }}$ and $4^{\text {th }}$ Instar larvae of $S$. cerealella

Twenty four hours old ten newly hatched first instars larvae were collected from infected wheat grains. These $1^{\text {st }}$ instars were kept in a $7 \mathrm{~cm}$ long and $1 \mathrm{~cm}$ diameter test tube and exposed to IR for selected time periods (15, 30 and 60 seconds) and temperatures (40 $\& 50{ }^{\circ} \mathrm{C}$.) with three replicates for each treatment. Control $1^{\text {st }}$ instars were not exposed to any IR exposure. Each tube was supplied with $5 \mathrm{gm}$ of nutrition powder to feed larvae. Tubes were blocked with sterilised gauze and covered with mousseline cloth for proper aeration and incubated in an incubator at $30 \pm 2^{\circ} \mathrm{C}$ temperature and $70 \pm 5 \%$ RH. Mortality, first larval and pupal stage period, pupae and emerging adults numbers were recorded. Mortality percentage was calculated after 14 hours of exposures to the 7 days for each stage larval, pupal and adults. Similar conditions were also applied for the $4^{\text {th }}$ instar larvae and data has been recorded on its mortality, larval and pupal stage period, pupae and emerging adults' numbers.

\subsubsection{Effect of IR ray on 24 hours old pupae of S. cerealella}

To estimate the effect of IR on 24 hours old pupae, ten freshly hatched pupae were collected in $9 \mathrm{~cm}$. diameter Petri dish and exposed to IR for three different exposure times $(15,30$ and 60 seconds) and two selected temperatures $\left(40 \& 50{ }^{\circ} \mathrm{C}\right.$.) with three replicates for each treatment. Dishes (except the control dishes) were subjected to the treatments and put in the IR device $10 \mathrm{~cm}$. away from the source. Dishes were covered with mousseline cloth and incubated at $30 \pm 2{ }^{\circ} \mathrm{C}$ and $70 \pm 5 \% \mathrm{RH}$. Data related to mortality was recorded from 12 hours of exposures to the seven days. Pupal time and deformation percentage (if found) were also recorded.

\subsubsection{Effect of IR ray on $S$. cerealella adults}

Twenty four hours old adults (5 pairs per experimental unit), were collected in $8.5 \mathrm{~cm}$ long and 2.5 diameter test tube and exposed to IR for three different exposure times (15, 30 and 60 seconds) at two selected temperatures $\left(40 \& 50{ }^{\circ} \mathrm{C}\right.$.) with three replicates for each treatment. Rest of the experimental conditions were similar to the previous section and data related to mortality were recorded.

\subsubsection{Effect of IR ray on Wheat (Triticum aestivum) grains germination}

To evaluate the effect of IR on wheat grain germination, twenty healthy wheat grains were selected. Seeds were taken into $9 \mathrm{~cm}$ diameter Petri dishes with waterlogged filter papers and were exposed to IR for the pre-decided exposure time and temperatures. Each dish was supplied with $5 \mathrm{ml}$ of water and incubated at $30 \pm 2$ ${ }^{\circ} \mathrm{C}$ temperature and $70 \pm 5 \% \mathrm{RH}$. Germination percentage recorded daily for five days as mentioned below:

$$
\begin{aligned}
& \text { Percentage of germination } \\
& =(\text { Germinating Seeds counts } / \text { Total Seeds }) \times 100
\end{aligned}
$$

\section{Results and Discussion}

\subsection{Effect of IR ray on 24 hours old eggs of $S$. cerealella}

Effect of the IR rays on egg mortality was represented in table 1. Results of the study revealed a significant effect of IR on the egg mortality, and it increased with the increase of temperature and exposure time. Among various exposure time and temperature intervals, the highest mortality $(56.7 \%)$ was reported at 60 seconds exposure and $50^{\circ} \mathrm{C}$ temperature which was followed by the same exposure time on $40^{\circ} \mathrm{C}$ temperature $(43.3 \%)$. In IR treatments, lowest egg mortality $(6.7 \%)$ was reported from the 15 second exposure time and $40^{\circ} \mathrm{C}$ temperature while overall lowest egg mortality was reported from the control (3.3\%) without IR treatment.

In the case of hatching period, no significant differences were reported and all the exposure time and temperature showed almost similar hatching periods. High exposure time and temperature caused delays in hatching and highest hatching period was 6.1 days which was reported at 60 -second exposure and $50^{\circ} \mathrm{C}$. While in control without IR exposure this hatching period was only 4.5 days. Results of this study are in agreement with the findings of Khamis et al. (2011) who reported significant reduction in the $S$. oryzae eggs hatching in wheat grains and it was affected by temperature and distance from IR. IR treatment increases cell temperature which increase egg mortality and inhibit egg hatching. Mahroof et al. (2003) determined time-mortality relationships for eggs, neonate larvae, old larvae, pupae, and adults of the red flour beetle. Kirkpatrick (1975b) reported 493\% egg mortality when wheat grain infested with rice weevils and lesser grain borers were exposure to infrared radiation at $43.38^{\circ} \mathrm{C}$. Further, Kirkpatrick (1975a) suggested that eggs and early instars of the lesser grain borer and Angoumois grain moth were more resistant to infrared treatments than eggs and early instars of rice weevils.

\subsection{Effect of IR ray on 24 hours old $1^{\text {st }}$ Instar larvae}

Effect of IR on $1^{\text {st. }}$ instar larvae has been given in Table 2. A significant effect of infrared radiation was reported on 1st Instar larvae, when these were exposed to IR for 15, 30 and 60 seconds at 40 and $50^{\circ} \mathrm{C}$. Among various tested combinations, the highest $1^{\text {st. }}$ instar mortality (36.7 and $53.3 \%$ ) was reported on the 60 second exposure at both temperatures 40 and $50^{\circ} \mathrm{C}$ respectively while the lowest value was reported from 15 second exposure at 40 and $50^{\circ}$ C. This value was 3.3 and $6.7 \%$ respectively for this exposure.

No significant difference was reported in larval period and longest $1^{\text {st. }}$ larval stage was reported at 60 seconds exposure ( 6.0 and 6.5 days on 40 and $50^{\circ} \mathrm{C}$ respectively) while it was reported 4.3 and 4.5 days on the 15 seconds exposure on the same temperatures. Similarly, exposure of IR also affected the development of pupae; minimum pupa development $(63.3 \%)$ was reported at 60 seconds exposure at $40^{\circ} \mathrm{C}$. 
Table 1 Effect of the IR rays exposure on the egg's hatching and mortality

\begin{tabular}{|lccc|}
\hline Temperature & Exposure (In Seconds) & Egg mortality \% & \multicolumn{2}{c|}{ Hatching period (days) } \\
\hline Control & 0 & 3.30 & 4.5 \\
\hline $\mathbf{4 0}$ & 15 & 6.70 & 4.5 \\
\cline { 2 - 4 } & 30 & 23.3 & 5.0 \\
\cline { 2 - 5 } & 60 & 43.3 & 5.8 \\
\hline L.S.D. $\mathbf{0 . 0 5}$ & & 5.84 & 0.32 \\
\hline $\mathbf{5 0}$ & 15 & 10.0 & 4.6 \\
& 30 & 36.7 & 5.3 \\
& 60 & 56.7 & 6.1 \\
\hline
\end{tabular}

Table 2 Effect of the Infra-red Ray on the development of 24 hours old, $1^{\text {st }}$ instar of S. Cerealella

\begin{tabular}{|c|c|c|c|c|c|c|}
\hline $\begin{array}{c}\text { Temperature } \\
\text { (C.) }\end{array}$ & $\begin{array}{l}\text { Exposure } \\
\text { (Seconds) }\end{array}$ & $\begin{array}{c}1^{\text {st }} \text { larval stage } \\
\text { mortality } \%\end{array}$ & $\begin{array}{l}\text { 1st larval stage } \\
\text { period (Days) }\end{array}$ & Pupae \% & $\begin{array}{l}\text { Average pupal } \\
\text { period (Days) }\end{array}$ & $\begin{array}{c}\text { Emerging adults } \\
\%\end{array}$ \\
\hline Control & 0 & 1.30 & 4.1 & 98.7 & 5.1 & 98.7 \\
\hline \multirow[t]{3}{*}{40} & 15 & 3.30 & 4.3 & 96.7 & 5.3 & 96.7 \\
\hline & 13 & 20.0 & 5.0 & 80.0 & 5.6 & 80.0 \\
\hline & 60 & 36.7 & 6.0 & 63.3 & 6.3 & 56.7 \\
\hline L.S.D. 0.05 & & 5.53 & 0.31 & 6.64 & 0.22 & 7.03 \\
\hline \multirow[t]{3}{*}{50} & 15 & 6.70 & 4.5 & 93.3 & 5.5 & 93.3 \\
\hline & 30 & 30.0 & 5.5 & 70.0 & 6.3 & 66.7 \\
\hline & 60 & 53.3 & 6.5 & 46.7 & 7.0 & 36.7 \\
\hline L.S.D. 0.05 & & 13.56 & 0.46 & 14.28 & 0.44 & 19.38 \\
\hline
\end{tabular}

It was followed $(46.7 \%)$ by the same exposure time at $50^{\circ} \mathrm{C}$. On the other hand, highest pupa development (96.7 and $93.3 \%$ ) was reported at 15 seconds exposure at 40 and $50^{\circ} \mathrm{C}$ respectively. The longest accumulated pupation period was 6.3 and 7.0 days for 60 seconds of exposure at 40 and $50^{\circ} \mathrm{C}$, but it was not significantly different from the 15 second exposure at 40 and $50^{\circ} \mathrm{C}$ which showed 5.3 and 5.5 days. Minimum adults' emerging percentage was 56.7 and $36.7 \%$ which was reported with 60 seconds exposure and at 40 and $50^{\circ} \mathrm{C}$ temperatures respectively while this value was 96.7 and $93.3 \%$ for the 15 seconds treatment at the same temperature range respectively. Similar types of results were reported by Khamis et al. (2011) in their study on S. oryzae that showed the IR effect on larvae increases by exposure time and distance from the ray source. Tilton \& Schroeder (1963) also reported similar effect of IR on the rate of adult emergence of rice weevils, lesser grain borers, and Angoumois grain moths from rice. Recently, Subramanyam (2004 \& 2005) reported sawtoothed grain beetle, rice weevil, red flour beetle, lesser grain borer and merchant grain beetle, Oryzaephilus Mercator (Fauvel) (Coleoptera: Silvanidae) adult mortality by exposing infrared radiation.

3.3 Effect of Infrared Ray on the development of S. cerealella 4th instar larvae

Table 3 showed significant differences between 40 and $50^{\circ} \mathrm{C}$ temperature factor with 30 and 60 seconds exposure to IR. The highest 4 th instar larvae mortality was 30 and $50 \%$ consequently at 60 seconds on 40 and $50^{\circ} \mathrm{C}$ while it was 16.7 and $26.7 \%$ for 30 seconds exposure at the same temperatures. In case of control, no 4th instar larvae mortality was reported in this study.

In case of larval stage duration, longest larval duration were 6.3 and 7 days at 60 seconds on 40 and $50^{\circ} \mathrm{C}$ temperature while in the case of control and 30 seconds exposure this value was reported 4.7 and 5.3 days respectively. In the case of pupation percentage, the minimum population was reported from 60 seconds exposure and this value was 70 and $50 \%$ at 40 and $50^{\circ} \mathrm{C}$., but it was 83.3 and $73.3 \%$ when exposure was 30 seconds on 40 and $50^{\circ} \mathrm{C}$. Pupae took 6.5 and 7.1 days in converting adults when these were exposed to IR for 60 seconds at 40 and $50^{\circ} \mathrm{C}$ temperature while this period was 6.1 days when these pupae exposed to IR for 30 seconds.

Emerging adults' percentage was minimum when the exposure was 60 seconds on 40 and $50^{\circ} \mathrm{C}$ respectively. At same temperature range, 30 second exposure gave 83.3 and $73.3 \%$ adult percentage. There were also significant differences in 15 seconds exposure for both $4^{\text {th }}$ larval instar and the pupation periods. It was $(5,5.1)$ and $(5.5,5.8)$ days on 40 and $50^{\circ} \mathrm{C}$ respectively as compared to the control which was 4.7 and 5.1 days for each. There was no significant difference at 15 seconds exposure in the $4^{\text {th }}$ larval instars, pupas and emerging adults on 40 and $50^{\circ} \mathrm{C}$. The results agree with the study of Khamis et al. (2010) those who studied the effect of IR on various stages of Rhyzopertha dominica, S. oryzae and Tribolium castaneum. Their results showed that mortality at all stages was affected by temperature and it was $99-100 \%$ when the temperature was $108-114^{\circ} \mathrm{F}$. 
Table 3 Effect of Infrared ray on the various developmental stages of $4^{\text {th }}$ instar larvae of $S$. cerealella

\begin{tabular}{|c|c|c|c|c|c|c|}
\hline $\begin{array}{c}\text { Temperature } \\
\text { (C.) }\end{array}$ & $\begin{array}{l}\text { Exposure } \\
\text { (Seconds) }\end{array}$ & $\begin{array}{l}4^{\text {th }} \text { larval stage } \\
\text { mortality } \%\end{array}$ & $\begin{array}{c}4^{\text {th }} \text { larval stage } \\
\text { period (Days) }\end{array}$ & $\begin{array}{c}\text { Pupae } \\
\%\end{array}$ & $\begin{array}{c}\text { Average pupal } \\
\text { period (Days) }\end{array}$ & $\begin{array}{c}\text { Emerging } \\
\text { adults \% }\end{array}$ \\
\hline Control & 0 & 0 & 4.7 & 100 & 5.1 & 100 \\
\hline \multirow[t]{3}{*}{40} & 15 & 0 & 5.0 & 100 & 5.5 & 100 \\
\hline & 30 & 16.7 & 5.3 & 83.3 & 6.1 & 83.3 \\
\hline & 60 & 30.0 & 6.3 & 70.0 & 6.5 & 63.3 \\
\hline L.S.D. 0.05 & & 9.77 & 0.34 & 7.54 & 0.34 & 13.16 \\
\hline \multirow[t]{3}{*}{50} & 15 & 0 & 5.1 & 100 & 5.8 & 100 \\
\hline & 30 & 26.7 & 6.0 & 73.3 & 6.5 & 73.3 \\
\hline & 60 & 50 & 7.0 & 50.0 & 7.1 & 43.3 \\
\hline L.S.D. 0.05 & & 18.61 & 0.46 & 17.37 & 0.33 & 16.93 \\
\hline
\end{tabular}

Table 4 Effect of Infrared ray on 24 hours old pupae development

\begin{tabular}{|c|c|c|c|c|c|}
\hline $\begin{array}{c}\text { Temperature } \\
\left({ }^{\circ} \mathbf{C}\right)\end{array}$ & $\begin{array}{l}\text { Exposure } \\
\text { (Seconds) }\end{array}$ & $\begin{array}{c}\text { Pupae mortality } \\
(\%)\end{array}$ & $\begin{array}{c}\text { Pupae stage period } \\
\text { (Days) }\end{array}$ & Emerging Adults (\%) & Deformations (\%) \\
\hline Control & 0 & 0.0 & 5.1 & 100 & 0.0 \\
\hline \multirow[t]{3}{*}{40} & 15 & 0.0 & 5.3 & 100 & 0.0 \\
\hline & 30 & 16.7 & 5.5 & 83.3 & 0.0 \\
\hline & 60 & 26.7 & 6.1 & 73.3 & 3.3 \\
\hline L.S.D. 0.05 & & 9.88 & 0.33 & 6.57 & 1.69 \\
\hline \multirow[t]{3}{*}{50} & 15 & 0.0 & 5.6 & 100.0 & 0.0 \\
\hline & 30 & 20.0 & 6.3 & 80.0 & 0.0 \\
\hline & 60 & 43.3 & 7.0 & 56.7 & 10.0 \\
\hline L.S.D. 0.05 & & 19.09 & 0.42 & 18.75 & 6.33 \\
\hline
\end{tabular}

Table 5 Effect of Infrared ray exposure on adult of S. cerealella

\begin{tabular}{|lcc|}
\hline \multicolumn{1}{|c}{ Temperature (C.) } & $\begin{array}{c}\text { Exposure } \\
\text { (Seconds) }\end{array}$ & $\begin{array}{c}\text { Adult mortality } \\
\text { \% }\end{array}$ \\
\hline Control & 0 & 0 \\
\hline $\mathbf{4 0}$ & 15 & 6.7 \\
\cline { 2 - 3 } & 30 & 20 \\
\cline { 2 - 3 } & 60 & 46.7 \\
\hline L.S.D. 0.05 & & 4.34 \\
\hline $\mathbf{5 0}$ & 15 & 13.3 \\
\cline { 2 - 3 } & 30 & 36.7 \\
\hline L.S.D. 0.05 & 60 & 66.7 \\
\hline
\end{tabular}

3.4 Effect of the Infrared ray on 24-hours old pupae of S. cerealella

When twenty-four hours old pupae were exposed to IR, significant differences was reported between 40 and $50^{\circ} \mathrm{C}$ temperature at 30 and 60 seconds exposure as compared to the control. Highest pupae mortality was 26.7 and $43.3 \%$ at 60 seconds exposure at 40 and $50^{\circ} \mathrm{C}$ temperature, while it was 16.7 and $20 \%$ with 30 seconds on the both temperatures $\left(40\right.$ and $\left.50^{\circ} \mathrm{C}\right)$ respectively. The Longest pupation period was 6.1 and 7 days with 60 seconds exposure at 40 and $50^{\circ} \mathrm{C}$ and it was 5.5, 6.3 days for 30 seconds exposure on the same temperatures respectively but for the control this value was 5.1 days.

Adults emerging percentage with 60 seconds exposure at 40 and $50^{\circ} \mathrm{C}$ was 73.3 and $56.7 \%$ respectively while it was reported 83.3 and $80 \%$ on the exposure of 30 seconds at the same temperatures respectively while for the control, $100 \%$ larval emergence was reported (Table 4). Pupation period study results showed significance differences at 15 seconds at 40 and $50^{\circ} \mathrm{C}$. It was 5.3 and 5.6 days compared to the control which have 5.1 days. Results presented in table 4 did not show any significance difference in pupae mortality and adults emerging percentage with 15 seconds exposure on the same temperatures. On the exposure of 60 seconds at 40 and $50^{\circ} \mathrm{C}$, table 4 shows 3.3 and $10 \%$ deformation of emerging adults, but it was $0 \%$ with the control treatment. Results agreed with Kirkpatrick et al. (1973) when they evaluated the I.R., Gamma Ray and their combination effect on various life stages of $R$. dominica on wheat. The researchers reported that pupae were affected by increasing IR exposure time. 
Table 6 Effect of the Infrared ray on wheat seeds T. aestivum germination

\begin{tabular}{|lcc|}
\hline \multicolumn{1}{|c}{ Temperature (C.) } & $\begin{array}{c}\text { Exposure } \\
\text { (Seconds) }\end{array}$ & $\begin{array}{c}\text { Seeds } \\
\text { germination \% }\end{array}$ \\
\hline Control & 0 & 90.0 \\
\hline 40 & 15 & 91.6 \\
\cline { 2 - 3 } & 30 & 93.3 \\
\cline { 2 - 3 } & 60 & 95.0 \\
\hline L.S.D. 0.05 & & 3.05 \\
\hline 50 & 15 & 91.7 \\
\cline { 2 - 3 } & 30 & 95.0 \\
\hline L.S.D. 0.05 & 60 & 96.0 \\
\hline
\end{tabular}

3.5 Effect of Infrared ray on S. cerealella adults

When S. cerealella adults were exposed to IR rays, significant differences were reported in various temperature range and time of exposure (Table 5). Highest adult mortality was reported on the exposure of 60 seconds for 40 and $50^{\circ} \mathrm{C}$, and it was 46.7 and $66.7 \%$ respectively. On the exposure of 30 seconds, 20 and $36.7 \%$ adult mortality was reported at the same temperatures (40 and $50^{\circ} \mathrm{C}$ ) consequently. Reduction in exposure time caused a decline in mortality rate, and lowest mortality was reported in the control treatments. These results show similarity with the findings of Mohammad \& Amerah (2013), these researchers identify lethal effect of I.R. on some stored wheat and wheat flour insects. They reported that exposure of 180 seconds to IR, raised the flour temperature and killed $58.67 \%$ of Tribolium castaneum. They also reported that 240 seconds exposure of IR raised the temperature of the grain and causing the death of $60 \%$ of Sitophilus granaries and $56.67 \%$ of Rhizopertha dominica. They concluded that increase in the exposure time and decrease in the distance from the ray source caused increasing in temperature and mortality.

3.6 Effect of Infrared Ray effect on wheat (Triticum aestivum) grains germination

Result of this study indicated a significat effect of inferred radiation on all the stages of $S$. cerealella. Effect of these radiation on the wheat grain was also evaluated in present study. To assess the effect of these IR rays on wheat seed germination, wheat seed were also exposed to selected time durations (15, 30 and 60 seconds) and temperature ranges $\left(40\right.$ and $\left.50^{\circ} \mathrm{C}\right)$. Results presented in Table 6 showed no significance effect of infrared rays on wheat seed germination. All the treatments showed almost similar germination, which indicates that IR does not affect the seed germination but have the capability to kill the seed insects. Because of this phenomenon, IR can be used as an effective pest control measure. In this study some difference in the seed germination was reported, this may be because of genetic or environmental factors. Here highest and lowest seed difference was reported at 60 second exposure and control treatments. A similar type of results was obtained by Kirkpatrick (1975b). They indicated that wheat and rice grains could resist IR temperature up to $80^{\circ} \mathrm{C}$ without any effect on the flour or bread quality.

\section{Conflict of interest}

Authors would hereby like to declare that there is no conflict of interests that could possibly arise.

\section{References}

Ashamo MO (2010) Relative resistance of paddy varieties to Sitotroga cerealella (Lepidoptera: Gelechiidae). Biologia 65: 333-337. doi:10.2478/s11756-010-0026-6.

Ashamu MO, Khanna SC (2006) Resistance to Angoumois grain moth, Sitotroga cerealella (Olivier) in paddy varieties. Annals of Plant Protection Sciences 14:368-373.

Athanassiou CG, Chiou A, Rumbos CI, Karagiannis A, Nikolidaki EK, Panagopoulou EA, Kouvelas A, Karathanos VT (2016) Effects of electric infrared heating with light source penetration on microbial and entomological loads of dried currants and their organoleptic characteristics. Journal of Pest Science 89: 931-943. DOI:10.1007/s10340-015-0727-2.

Butron A, Romay MC, Ordas A, Malvar RA, Revilla P (2008) Genetic and environmental factors reducing the incidence of the storage pest Sitotroga cerealella in maize. Entomologia Experimentalis et Applicata 128: 421-428. doi:10.1111/j.15707458.2008.00733.x

Dakshinamurthy A, Regupathy A (1988) Alternate rice field hosts of the Angoumois grain moth. International Rice Research Newsletter 13: 42-43 .

Duangkhamchan W, Phomphai A, Wanna R, Wiset L, Lohavanich J, Ronsse F, Pieters JG (2017) Infrared Heating as a Disinfestation Method Against Sitophilus oryzae and Its Effect on Textural and Cooking Properties of Milled Rice. Food Bioprocess Technology 10:284-295. DOI 10.1007/s11947-016-1813-z.

Germanov A (1982) Development and behavior of larvae of Angoumois grain moth, Sitotroga cerealella Oliv. under conditions of mass rearing. Rasteniev dni Naeuki 19: 87 -95.

Grewal SS, Atwal AS (1967) The influence of temperature and humidity on the development of Sitotroga cerealella Olivier (Lepidoptera: Gelechiidae). Journal of Research 6: 353 -358.

Hansen LS, Henrik S, Hell K (2004) Life Table Study of Sitotroga cerealella (Lepidoptera: Gelichiidae), a Strain from West Africa. Journal of Economic Entomology 97: 1484 1490. doi: http://dx.doi.org/10.1603/0022-0493-97.4.1484.

Hill DS (1990) Pests of stored products and their control. CRC Press, Boca Raton, FL, New Delhi, India, Pp 152-153. 
Khamis M, Subramanyam B, Dogan H, Flinn PW, Gwirtz JA ( 2011) Effects of flameless catalytic infrared radiation on Sitophilus oryzae (L.) life stages. Journal of Stored Products Research 47:173-178. DOI: http://doi.org/10.1016/j.jspr.2010.11.002.

Khamis M, Subramanyam B, Flinn PW, Dogan H, Jager A, Gwirtz JA (2010) Susceptibility of various life stages of Rhyzopertha dominica (Coleoptera: Bostrichidae) to flameless catalytic infrared radiation. Journal of Economic Entomology 103: 1508-1516. doi: http://dx.doi.org/10.1603/EC10069.

Khan I, Afsheen S, Din N, Khattak SUK, Khalil SK, Hayat Y, Lou Y (2010) Appraisal of Different Wheat Genotypes Against Angoumois Grain Moth, Sitotroga cerealella (Oliv.). Pakistan Journal of Zoology 42:161-188.

Kirkpatrick RL (1975a) The use of infrared and microwave radiation for control of stored-produce insects. In: Proceeding of First International Conference Stored Product Entomology, Savananah, GA, Pp. 431-437.

Kirkpatrick RL, Brower JH, Tilton EW (1973) Gamma, infrared and microwave radiation combinations for control of Rhyzopertha dominica in wheat. Journal of stored product Research 9: 19-23

Kirkpatrrick RL (1975b) Infrared radiation for control of lesser grain borers and rice weevils in bulk wheat (Coleoptera: Bostrichidae and Curculionidae). Journal of the Kansas Entomological Society - BioOne 48:100-104.

Mahroof R, Subramanyam B, Eustace D (2003) Temperature and relative humidity profiles during heat treatment of mills and its efficacy against Tribolium castaneum (Herbst) life stages. Journal of Stored Products Research 39:555-569. DOI: http://doi.org/10.1016/S0022-474X(02)00062-0.

Mohammad S, Amerah MA (2013) Effect of infrared and gamma ray on some stored product on wheat. Molecular Biology Research Centre Egypt 13:102-114.

Pan Z, Khir R, Godfrey LD, Lewis R, Thompson JF, Salim A (2008) Feasibility of simultaneous rough rice drying and disinfestations by infrared radiation heating and rice milling quality. Journal of Food Engineering 84:469-479. DOI: http://doi.org/10.1016/j.jfoodeng.2007.06.005.
Penner MH (1998) Basic Principles of spectroscopy. In: Nielsen SS (Ed) Food Analysis Scond edition. Springer New York Dordrecht Heidelberg London Publication Pp. 375-385. DOI: 10.1007/978-1-4419-1478-1_21.

Rajendran S, Chayakumari (2003) Insect infestation and control in stored grain sorghum and millets. Journal of Food Science \& Technology 40:451-457.

Subramanyam B (2004) Hot technology for killing insects. Milling Journal First Quarter :48-50.

Subramanyam B (2005) Hot technology for killing insects [part II]. Milling Journal Fourth Quart. 2005:58-59.

Technical data OSRAM company U.S.A 2016. (Data about which subject, month, year, if possible provide ISBN no of pdf)

Trematerra P, Stejskal V, Hubert T (2011) The monitoring of semolina contamination by insect fragments using the light filth method in an Italian mill. Food control 22:1021-1026. DOI: http://doi.org/10.1016/j.foodcont.2010.11.026.

Tilton EW, Schroeder HW (1963) Some effects of infrared irradiation on the mortality of immature insects in kernels of rough rice. Journal of Economic Entomology 56: 727-730.

Trematerra P (2015) Adult dispersal of Sitotroga cerealella in a conventional small-farm in Southern Italy. Bulletin of Insectology 68: 111-118

Ukeh DA, Udo IA, Ogban EI (2008) Trapping of storedproduct insects using flight traps outside traditional African storage granaries. Journal of Food Agriculture and Environment 6: 399-401.

Wehling RL (1998) Infrared spectroscopy. In: Nielsen SS (Ed.), Food analysis, second edition. Aspen Publication, Gaithersburg, MD, Pp. 413-424.

Weston PA, Rattlingourd PL (2000) Progeny production by Tribolium castaneum (Coleoptera: Tenebrionidae) and Oryzaephilus surinamensis (Coleoptera: Silvanidae) on maize previously infested by Sitotroga cerealella (Lepidoptera: Gelechiidae). Journal of Economic Entomology 93: 533-536. DOI: https://doi.org/10.1603/0022-0493-93.2.533. 